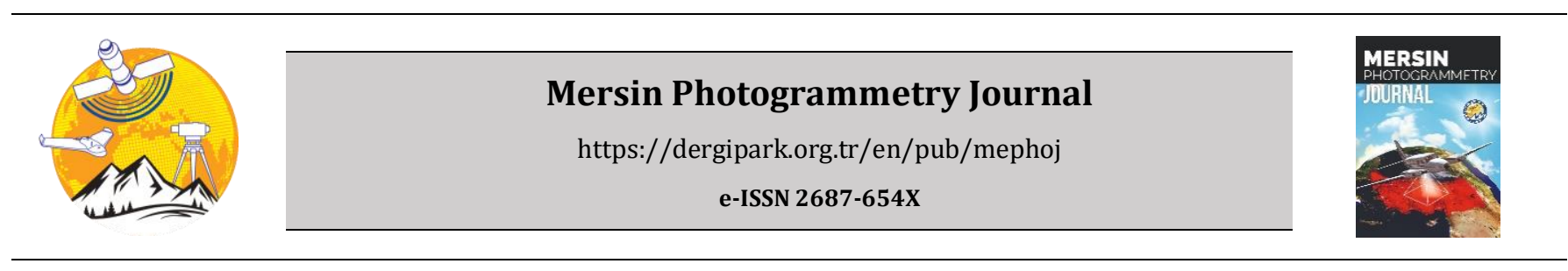

\title{
Digital documentation of ancient stone carving in Şuayip City
}

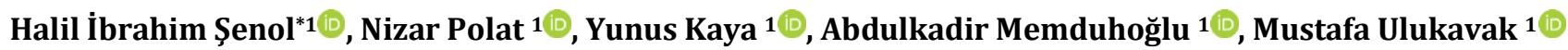 \\ ${ }_{1}^{1}$ Harran University, Engineering Faculty, Department of Geomatic Engineering, Sanlıurfa, Turkey
}

\author{
Keywords \\ SfM \\ Photogrammetry \\ Şuayip City \\ Archaeology
}

\begin{abstract}
Şanliurfa is an important archaeological and cultural region where people have left permanent artifacts dating back to 12 thousand years. For this reason, it is very important to record and document the artifacts in this region where cultural heritage is very intense. With the developing technology, it has become easier to document historical artifacts and to transfer them to future generations. In this direction, historical artifacts can be recorded easily and accurately with the photogrammetry technique, which is one of the important tools offered by developing technology. With this method, a detailed model of the historical artifact can be created and recorded in the digital environment. In this study, a point cloud and a 3D model of a carving stone, located in the region known as Şuayip City, located $80 \mathrm{~km}$ south of Şanlıurfa, was produced by photogrammetry, and the details of the carving stone were revealed. At the result of the study, the carving on the stone was revealed by using various filtering techniques.
\end{abstract}

\section{INTRODUCTION}

Cultural heritages unearthed in archaeological sites allow us to obtain information about past civilizations and to experience the spirituality of those times (Eskikurt, 2003; Yakar et al. 2015; Kaya et al., 2021). Also, it is an obligation to pass on the works of past civilizations to future generations. The efforts of human beings to leave a mark on the places they have lived since their existence make it possible for us to reach these artifacts after many years. Cultural heritage sites have great importance in terms of both cultural tourism and ongoing scientific studies in these areas. Cultural heritages can be examined under three headings as concrete, intangible and natural heritages (Ulvi et al., 2019a). Thanks to tangible cultural heritages such as painting, sculpture, buildings, clothing, and objects, it can be seen to what extent the daily lives and civilizations of the communities that lived in the past have progressed. While the materials from which the objects found in the archaeological areas are conveyed to us the conditions of that day, artistic structures such as painting, and sculpture are also a message from the past centuries to the present.
Historical artifacts are in danger of being damaged or destroyed over time due to natural or human factors (Cömert et al., 2012; Tercan, 2017). Documentation of cultural heritage has gained momentum in parallel with the development of technology. Documentation of cultural heritages allows both the object features to be examined in more detail and to be recorded and to take measures against disruptions such as accidents and natural disasters that may occur in the coming years. Many methods have been used to document small objects or large structures that can count as cultural heritage. However, when the studies in the literature are examined, it is seen that taking pictures is easier than other methods (Yakar et al. 2016; Ulvi et al., 2019a). In the photogrammetry technique, which is a good alternative to traditional methods in the documentation of cultural heritage, photographs of the object can be obtained, and a 3D model can be generated with the help of certain mathematical models. Ulvi et al. (2019b) conducted a study on the modeling of historical fountains using the close-range photogrammetry method. Yakar and Doğan (2018) examined the use of the SfM method in different study areas and stated that it gives consistent results in archaeological sites. Today, due to the relatively inexpensive and portable nature of 
digital handheld cameras, terrestrial photogrammetry is frequently used in archaeological sites (Ulvi et al., $2019 b)$. Digital handheld cameras used in terrestrial photogrammetry can be calibrated both before and during the task and store the information required for 3D modeling. In this way, 3D models can be obtained with calibrated cameras. By using superimposed photographs with the Structure from Motion (SfM) method, a 3D model of the object can be generated.

The name of the city of Şanlıurfa has become popular not only throughout the country but also throughout the world, thanks to the cultural heritage in the province. Göbeklitepe (Kurt and Göler, 2017), Karahantepe (Çelik, 2011), Harran City (Green, 1992), Soğmatar (Albayrak and Çelik, 2019) and many others are important archaeological sites which attracts the local and foreign tourists. Many archaeological excavations and academic studies have been carried out in these areas from the past to the present. Şenol et al. (2020) used terrestrial laser scanner and drone data to model the Kizllkoyun Rock Tombs. Polat et al. (2020) modeled small objects extracted at the Harran Archaeological Site with the photogrammetry method and transferred them to digital environment in a scaled and precise manner. Şenol et al. (2017) used the terrestrial laser scanning method to model the city of Harran in their study. Ulukavak et al. (2019) modeled the Harran ruins with the photogrammetric method. Although there are studies on the Harran and Göbeklitepe archaeological sites in the province of Şanlıurfa in the literature, there are not many studies on the ancient city of Şuayip, which is the subject of this study.

In this study, the inscription on the wall next to the entrance door of a cave in the ancient city of Şuayip was examined. Unearthing and documenting this inscription, which is an important heritage related to the region, is critical for the continuity of the cultural heritage. Accordingly, in this study, the 3D documentation, automatic drawing and visualization of the inscription engraved on the wall were made.

\subsection{Study Area}

The ancient settlement known as Şuayip City, which constitutes the study area, is located in the Tektek Mountains approximately $80 \mathrm{~km}$ southeast of Şanlıurfa (Figure 1). It is understood that the settlement is spread over a low rocky hill and its skirts.

Although the ancient name of the settlement is not known precisely, there are suggestions regarding it (Sinclair 1990, 189-190; Lipinski, 2000, 124; Güler, 2016,170). The belief that Prophet Şuayip lived here for a while and the acceptance of one of the rock settlements in the area as the quarter of Prophet Şuayip has resulted in this settlement being called "Şuayip City" today.

Although the buildings in the area are mostly from the Late Antique Era, it is suggested that some of them may have been built in the first century (7th century) of the Arab invasion (Sinclair 1990, 189-190). Two different architectures stand out in the field within the framework of the first observations. These are the spaces carved into the bedrock and the structures made of cut block stones on the bedrock. Besides, the presence of some structures made of cut blocks and stairs leading down to the rooms carved into the bedrock below were found. This shows that rock settlements and structures made of cut blocks are used together and that two different architectural approaches constitute a single structure.

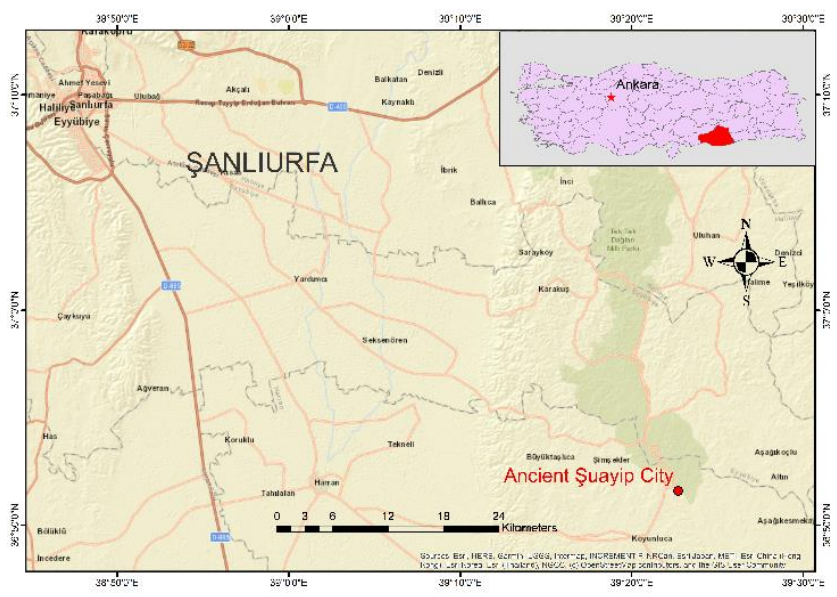

Figure 1. Study area

As seen from the surface remains, the structures made of cut block stones are mainly concentrated on the northern and western slopes of the hill. Some of these structures, which are seen at the level of footing blocks in most of the area or are under the ground, have been preserved until today to give surface architecture. In this study, a carving stone found in the city of Şuayip was examined (Figure 2).

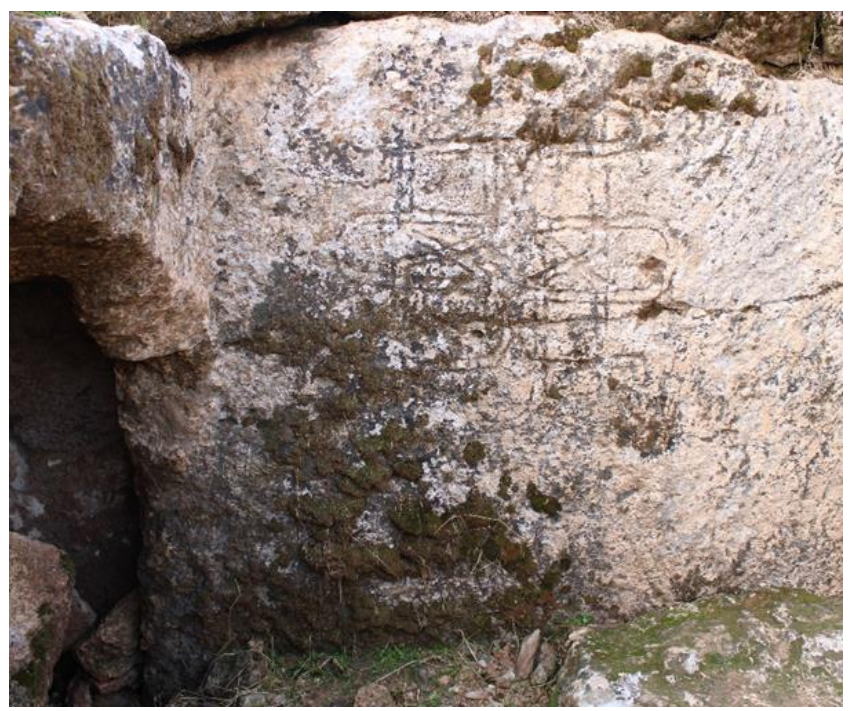

Figure 2. Carving stone

It is observed that the carving stone deforms over time and becomes incomprehensible. For this reason, the deformed area was examined with the photogrammetry technique and the photographs of the carving stone were taken with the terrestrial photogrammetry technique.

\subsection{Equipment}

Canon 2000D DSLR camera was used in the study (Figure 3). To document the archaeological site using 
the terrestrial photogrammetry technique and to obtain a 3D model, it is necessary to take overlapping photographs to cover the entire structure. Information about the digital camera used in the study is given in Table 1.
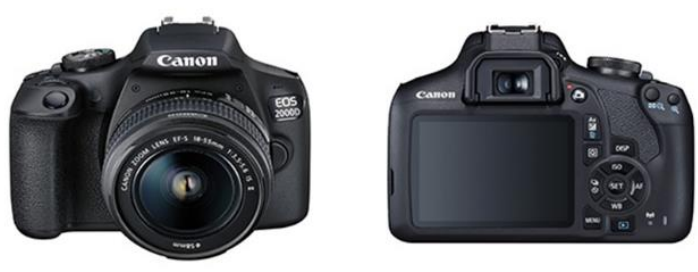

Figure 3. The camera used in this study

Table 1. Equipment specifications

\begin{tabular}{ll}
\hline Feature & $2000 \mathrm{D}$ \\
& Value \\
\hline Megapixels & 24.1 \\
Maximum Image Resolution & $6000 \times 4000$ pixels \\
Weight & $475 \mathrm{~g}$ \\
& $129 \times 101.3 \times 77.6$ \\
Size & $\mathrm{mm}$ \\
Sensor Size & $22.3 \times 14.9 \mathrm{~mm}$ \\
\hline
\end{tabular}

\section{METHOD}

Terrestrial photogrammetry is a method that enables 3D drawings to be made at near and far distances. By using cameras with different focal lengths and special software, necessary orientations are made and 3D models are produced from the photographic surface. With this method, 3D location information of the objects whose models are obtained is created (Şanlıoğlu et al., 2013). Terrestrial photogrammetry is used in many application areas. These areas are preferred in architecture, archeology, industry, land surveys, medicine, criminology, traffic accidents, and many other areas. Thanks to CAD-based software, the application areas of terrestrial photogrammetry are shifting to different areas according to the imagination of the person (Ulvi et al., 2020).

Survey plans, orthophoto, profile extractions, and 3D models obtained from photographs taken from historical buildings are used to document cultural heritage. In this way, it is possible to reconstruct cultural values that may be deformed or damaged over time.

SfM is a photogrammetric method used to create 3D models of a feature or topography from twodimensional photographs that overlap in many positions and directions to recreate the photographed object (Figure 4).

This technology exists in various forms since 1979, but applications were not common until the early 2000s. SfM technique is a method that can model the object in 3D in the digital environment by using many images of a 3D object taken from different angles. Traditional photographic techniques require precise 3D location and orientation information of cameras and control points for geometric modeling. On the other hand, model geometry, camera position and orientation information can be calculated simultaneously and automatically in the SfM method (Snavely et al., 2008; Önal et al., 2017).

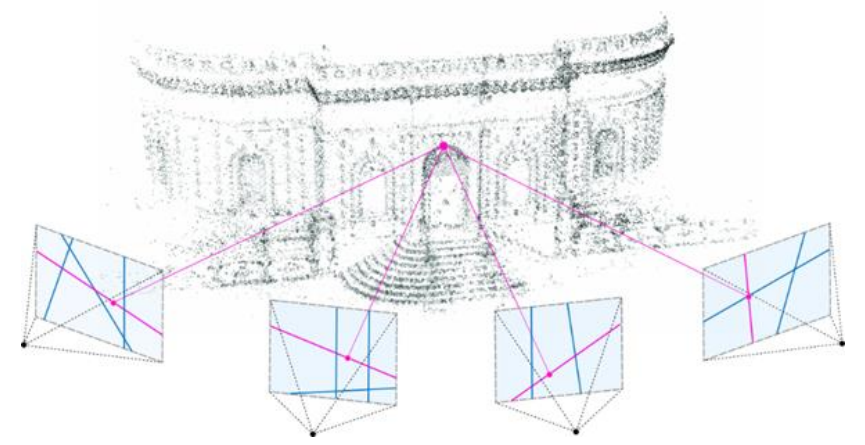

Figure 4. SfM method (Geppert et al., 2020)

SfM's applications range from many geology subfields (geomorphology, tectonics, structural geology, geodesy, mining) to archeology, architecture, and agriculture. In addition to orthorectified images, SfM generates a dense point cloud dataset like those produced by airborne or terrestrial LiDAR.

\section{APPLICATION AND RESULTS}

For 3D modeling, a total of 42 photographs of the object were taken from different angles. The shooting was done with a Canon 2000D camera. In the SFM technique, since the model geometry and camera position information are resolved simultaneously and automatically, there is no need for camera calibration (Sarıtürk \& Şeker, 2017).

Agisoft PhotoScan software is a photo-based modeling program that is often used to produce highquality 3D models from photographs. In this study, Agisoft PhotoScan software was preferred as commercial software. The photos obtained with the camera were transferred to the software, and a point cloud was created by matching the photos. Approximately 4.6 million points were produced in the model made with the terrestrial photogrammetry technique. The noise-generating points were cleaned and then a dense point cloud was formed. After cleaning the dense point cloud, the solid model was produced, and the 3D model was generated by using the texture information (Figure 5).
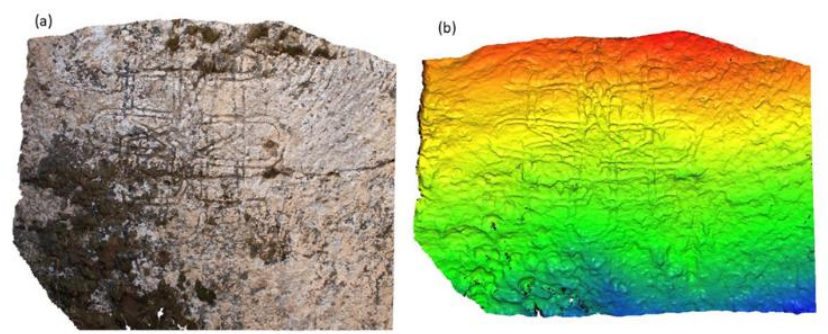

Figure 5. (a) Point cloud and (b) solid model

To reveal the inscription automatically, an elevation model was created first. The inscription was tried to be revealed by the depth through these elevation models (Figure 6). 

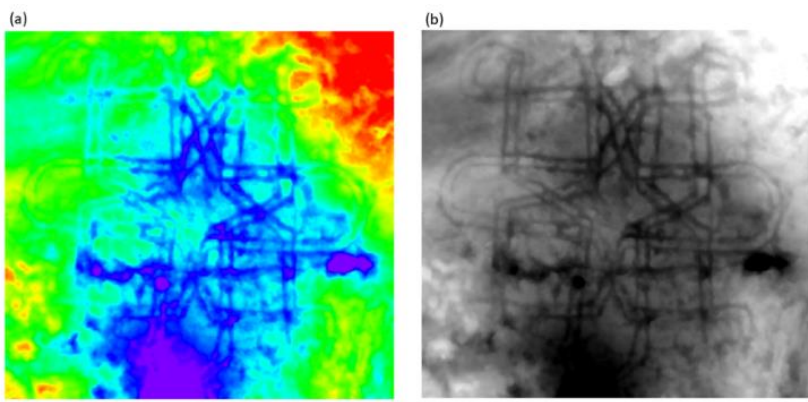

Figure 6. (a) Colored elevation model and (b) elevation model in grayscale

The height model was not sufficient to reveal the entire inscription. Different heights have emerged and inscription depths could not be obtained because of the surface deformation and mosses on the stone. So, the inscription was tried to be extracted by different analysis techniques using verticality, surface variation, directional and Gaussian high pass filters (Figure 7). (a)

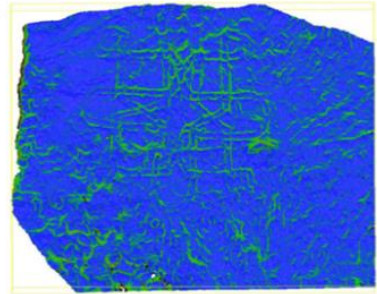

(c)

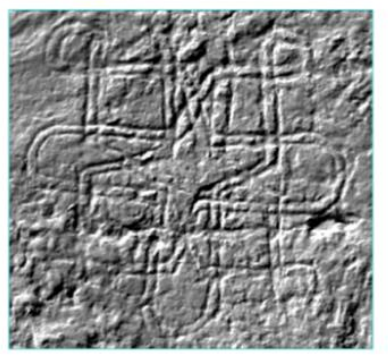

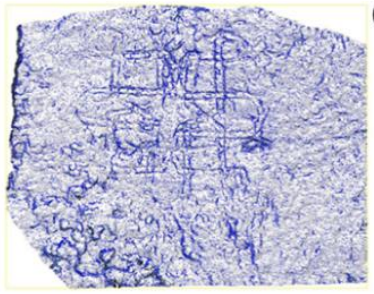

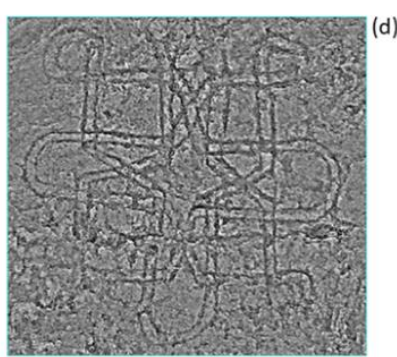

Figure 7. The results of; (a) verticality filter, (b) surface variation filter, (c) directional filter, and (d) Gaussian high pass filter

As seen in figure 7, the results of four different filters present valuable information to define the ancient stone carving. Especially the linear parts of the carving were highly emphasized.

\section{CONCLUSION}

In this study, the historical carving stone found in the archaeological excavation area of Şuayip city was modeled by photogrammetric methods. The modeling process was done by taking terrestrial photographs of the building. The fact that the surface of the carving stone was deformed too much, and the inscription depth was insufficient has been a struggle for the study. In this direction, first the point cloud and then the 3D model of the area was produced. As a result of the study, approximately 4.6 million points were produced by terrestrial photogrammetry. Although the elevation model was used at first to overcome the struggle encountered in the study, no meaningful result was obtained due to the roughness of the surface. Later, using filters such as verticality, surface variation, directional and Gaussian high pass, the inscription became visible and distinctive in detail. With the carving stone's revealing and detailed modeling, Şuayip Ancient City which is one of Turkey's forgotten cultural heritage has led to the discovery and saving. Although the photogrammetry technique is sufficient for these studies, a solution can be produced by using the laser scanning method in future studies for such a deformed surface.

\section{ACKNOWLEDGMENT}

Supported by the Harran University's Research Projects Department, project number 20115.

\section{Author Contribution}

The authors' contributions are equal to all phases of the research and the article.

\section{Conflicts of interest:}

The authors declare no conflicts of interest.

\section{REFERENCES}

Albayrak Y \& Çelik B (2019). Soğmatar Çevresi Kaya Mezarları. Karadeniz Uluslararası Bilimsel Dergi, (43), 255-261.

Cömert R, Avdan U, \& Şenkal E (2012). İnsansız Hava Araçlarının Kullanım Alanları ve Gelecekteki Beklentiler. IV. Uzaktan Algılama ve Coğrafi Bilgi Sistemleri Sempozyumu (UZAL-CBS 2012), 16-19, Zonguldak.

Çelik B (2011). Karahan Tepe: a new cultural centre in the Urfa area in Turkey. Documenta Praehistorica, $38,241-254$.

Eskikurt A (2003). Anadolu medeniyetleri ve coğrafya. Doktora tezi. Erişim Adresi: http://dspace.marmara.edu.tr/handle/11424/2 7726

Geppert M, Larsson V, Speciale P, Schönberger J L, \& Pollefeys M (2020). Privacy preserving structurefrom-motion. In European Conference on Computer Vision (pp. 333-350). Springer, Cham.

Green T M (1992). The City of the Moon God: Religious Traditions of Harran (Vol. 114). Brill.

Guler S E (2016). Urfa Tarihinden Sayfalar, Eyyübiye Bel. Yayınları, Ankara.

Kaya Y, Yiğit A Y, Ulvi A, \& Yakar M (2021). Arkeolojik Alanların Dokümantasyonununda Fotogrametrik Tekniklerinin Doğruluklarının Karşılaştırmalı Analizi: Konya Yunuslar Örneği. Harita Dergisi, 165, 57-72.

Kurt A O \& Göler M E (2017). Anadolu'da İlk Tapınak: Göbeklitepe. Cumhuriyet Illahiyat Dergisi, 21(2), 1107-1138.

Lipinski E (2000). The Aramaeans: Their Ancient History Culture, Religion, (Orientalia Lovaniensia Analecta), Peeters. 
Önal O, Bozdağ Ö \& Ersoy A (2017). İzmir Agorası'ndaki Roma Dönemine Ait Hamam Yapısının SFM Tekniği ile 3 Boyutlu Katı Modelinin Olușturulması. 6. Tarihi Yapıların Korunması ve Güçlendirilmesi Sempozyumu.

Polat N, Önal M, Ernst F B, Şenol H İ, Memduhoglu A, Mutlu S, Mutlu S İ, Budan M A, Turgut M \& Kara H (2020). Harran Ören Yeri Arkeolojik Kazı Alanınındın Çıkarılan Bazı Küçük Arkeolojik Buluntuların Fotogrametrik Olarak 3B Modellenmesi. Türkiye Fotogrametri Dergisi, 2(2), 55-59.

Sarıtürk B \& Şeker D Z (2017). Sfm Tekniği ile 3b Obje Modellenmesinde Kullanılan Ticari ve Açık-Kaynak Kodlu Yazılımların Karşılaştırılması. Afyon Kocatepe Üniversitesi Fen Ve Mühendislik Bilimleri Dergisi, 17(4), 126-131.

Senol H I, Erdogan S, Onal M, Ulukavak M, Memduhoglu A, Mutlu S, Ernst F B \& Yilmaz M (2017). 3D Modelıng Of A Bazaar In Ancient Harran City Using Laser Scanning Technique. International Archives of the Photogrammetry, Remote Sensing \& Spatial Information Sciences, 42.

Sinclair T A (1990). Eastern Turkey: An Architectural and Archaeological Survey, Vol.IV, The Lindar Press, Londos, ss. 189-190.

Snavely N, Seitz S M \& Szeliski R (2008). Modeling the World from Internet Photo Collections. International Journal of Computer Vision 80, 189210.

Şanlıoğlu İ, Zeybek M \& Karauğuz G (2013). Photogrammetric Survey and 3D Modeling of Ivriz Rock Relief in Late Hittite Er. Mediterranean Arhaeology and Archaeometry, Vol. 13, No 2

Şenol H İ, Memduhoglu A \& Ulukavak M (2020). Multi instrumental documentation and 3D modelling of an archaeological site: a case study in Kizilkoyun
Necropolis Area. Dicle Üniversitesi Mühendislik Fakültesi Mühendislik Dergisi, 11(3), 1241-1250.

Tercan E (2017). İnsansız Hava Aracı Kullanılarak Antik Kent ve Tarihi Kervan Yolunun Fotogrametrik Belgelenmesi: Sarıhacılar Örneği. Mühendislik Bilimleri ve Tasarım Dergisi, 5(3), 633-642. doi: 10.21923/jesd.315232

Ulukavak M, Memduhoğlu A, Şenol H İ \& Polat N (2019). The use of UAV and photogrammetry in digital documentation. Mersin Photogrammetry Journal, 1(1), 17-22.

Ulvi A, Yakar M, Yiğit A \& Kaya Y (2019). The Use of Photogrammetric Techniques in Documenting Cultural Heritage: The Example of Aksaray Selime Sultan Tomb. Universal Journal of Engineering Science, 7(3), 64-73. doi: 10.13189/ujes.2019.070303

Ulvi A, Yakar M, Yiğit A Y \& Kaya Y (2020). İHA ve Yersel Fotogrametrik Teknikler Kullanarak Aksaray Kızıl Kilise'nin 3 Boyutlu Nokta Bulutu ve Modelinin Üretilmesi. Geomatik Dergisi, 5(1), 22-30.

Ulvi A, Yiğit A Y \& Yakar M (2019). Modeling of Historical Fountains by Using Close-Range Photogrammetric Techniques. Mersin Photogrammetry Journal, 1(1), 1-6.

Yakar M \& Dogan Y (2018). 3D Reconstruction of Residential Areas with SfM Photogrammetry. In Conference of the Arabian Journal of Geosciences (pp. 73-75). Springer, Cham.

Yakar M, Kabadayı A, Yiğit A Y, Çıkıkcı K, Kaya Y \& Catin S S (2016). Emir Saltuk Kümbeti Fotogrametrik Rölöve Çalişmasi Ve 3 Boyutlu Modellenmesi. Geomatik, 1(1), 14-18.

Yakar M, Orhan O, Ulvi A, Yiğit A Y \& Yüzer M M (2015). Sahip Ata Külliyesi Rölöve Örneği. TMMOB Harita ve Kadastro Mühendisleri Odası, 10. 